\title{
Molecular genetic analysis of some North African barley germplasms
}

\author{
*R. M. GAAFAR ${ }^{1}$, Mai ALLAM ${ }^{2}$, Rasha SABRY ${ }^{2}$ and M. SAKER ${ }^{2}$
}

Received February 22, 2016; accepted April 03, 2017.

Delo je prispelo 22. februarja 2016, sprejeto 03. aprila 2017.

\begin{abstract}
Isozyme and RAPD markers were used to characterize 29 barley accessions, which were collected from North Africa. In addition, resistance gene sequences were employed to develop molecular markers using RT-PCR approach. High level of polymorphism was found with both RAPD and isozyme markers, where RAPD showed that $60 \%$ of amplified bands were polymorphic. Peroxidase showed three polymorphic loci (7 allelic bands). Isozymes cluster analysis successfully separated the barley accessions into three geographically distinct groups. RAPD investigation demonstrated that Egyptian accessions were grouped into two obvious groups. Moreover, the Tunisian accessions showed no distinct clustering, while high dissimilarities were revealed by the Algerian accessions. In the RT-PCR, from six primer pairs selected, primer pair AF092524P1P2 successfully amplified two specific amplicons of approximately (340 \& $220 \mathrm{bp})$ and (360 \& 270 bp), respectively in two Egyptian barley genotypes (El-Awamah and Awlad-Ali). One primer pair DN988165P1P2 gave only one specific amplicon in both barley genotypes of 250 and $270 \mathrm{bp}$, respectively. The markers developed could be used in improving barley crop by assisting in breeding selection of resistance genotypes.
\end{abstract}

Key words: RT-PCR; resistance genes; barley; genetic diversity; RAPD

\section{IZVLEČEK}

\section{MOLEKULARNA GENETSKA ANALIZA NEKATERIH SEVERNOAFRIŠKIH GENSKIH VIROV JEČMENA}

Z izoencimskimi in RAPD markerji je bilo ovrednoteno 29 akcesij ječmena, nabranih $\mathrm{v}$ Severni Afriki. Za razvoj molekularnih markerjev na osnovi RT-PCR so bila uporabljena nukleotidna zaporedja genov za odpornost. Ugotovljen je bil velik polimorfizem RAPD in izoencimskih markerjev, kjer je bilo $60 \%$ namnoženih RAPD markerjev polimorfnih. Peroksidaza je pokazala tri polimorfne lokuse (7 alelelov). $\mathrm{Z}$ analizo izoencimskih skupin so bile akcesije ječmena uspešno razdeljene $v$ tri razločne geografske skupine. Raziskava RAPD je pokazala, da se egiptovske akcesije razločno povežejo $\mathrm{v}$ dve skupini. Tunizijske akcesije niso pokazale razločnega povezovanja, pri alžirskih pa so bile ugotovljene velike razlike. V RT-PCR analizi, je od šestih izbranih začetnih oligonukeltodiov par AF092524P1P2 uspešno namnožil dva specifična amplikona s približno 340 in 220 in 360 in 270 baznih parov pri dveh egiptovskih genotipih ječmena (El-Awamah in Awlad-Ali). Par začetnih oligonukleotidov DN988165P1P2 je pomnožil le en specifični fragment pri obeh genotipih ječmena z 250 in 270 baznimi pari. Razviti markerji se bodo lahko uporabili pri izboru genotipov za izboljšanje ječmena v žlahtnjenju na odpornost.

Ključne besede: RT-PCR; geni za odpornost; ječmen; genska raznolikost; RAPD markerji

\section{INTRODUCTION}

Barley (Hordeum vulgare L.) is one of the most pivotal cereal crops in the world. It is cultivated in the temperate zones. The haploid genome of barley is about $5.1 \mathrm{Gbp}$ (Mayer et al., 2012). Due to compatibility and inter-fertility of the cultivated and wild species (share a common genome, $\mathrm{n}=7$ ), wild species of barley and primitive landraces provide precious sources of genetic variability in a number of beneficial traits (Nevo, 1992; Ceccarelli et al., 1995). Consequently, search for genetic variation that might be useful for plant breeding programs is very essential as well as collection and conservation of wild relatives of the cultivated species and the endemic varieties (Brown et al., 1990).

PCR-based molecular markers (e.g. RAPD, SSR, STS, and ISSR) have been used in barley to uncover genetic variation, genotype identification and mapping of genes (Sánchez et al., 1996; Fernández et al., 2002; Matus and Hayes, 2002; Tanyolac, 2003). Particularly, RAPD markers are found to be valuable in case of self-

\footnotetext{
1 * Botany Department, Faculty of Science, Tanta University, Tanta, Egypt, corresponding author: redagaafar@ science.tanta.edu.eg

2 Plant Biotechnology Department, National Research Centre, Dokki, Giza, Egypt
} 
pollinating species, which show a relatively low level of intraspecific polymorphism, as in hexaploid wheat (Devos and Gale, 1992; Joshi and Nguyen, 1993) and in cultivated barley (Barua et al., 1993; Chalmers et al., 1993).

Recently, cDNA sequences are being used to develop markers, which are very useful since they are genebased markers (Parchman et al., 2010). Moreover, the progress in sequencing and documentation in public database has facilitated sequence data mining and development of DNA markers without any difficulty (Bhattachryya et al., 2014).

Resistance gene analogs (RGAs) were frequently found to be in close genetic distance to known resistance loci, hence suggesting their possible role in disease resistance responses in plants (Fourmann et al., 2001). The gene sequences, which encode proteins containing a nucleotide-binding site (NBS) and C-terminal leucinerich repeats (LRRs) constitute the largest class of $R$ genes in flowering plants (Dangl and Jones, 2001).
Wild barley has been known to carry valuable sources of useful genes for barley breeding. For example, genes that are associated with resistance to diseases (Fetch et al., 2003), tolerance to abiotic stress (Ellis et al., 2000), other key agronomic traits (Vanhala and Stam, 2006), and quality traits (Shen et al., 2011).

The development of new barley lines, tolerant to abiotic and biotic stresses is an essential part of the continued improvement of the crop. Moreover, it can assist in the amelioration of other relative crops. Wild barley would be a valuable source of novel genetic variation for environmental stress tolerance. However, it depends on identifying of suitable genetic variation and the development of marker-assisted selection, which allows effective cultivar development (Ellis et al., 2000).

The aims of this study are to uncover the genetic variability in a barley germplasm collected from North Africa, compare peroxidase isozymes and RAPD diversity in the studied materials, and amplify disease resistance sequences from some Egyptian landraces, which could be used as molecular markers in assisted marker selection of the resistance lines of barley.

\section{MATERIALS AND METHODS}

\subsection{Plant materials}

Twenty-nine cultivars, genotypes and landraces of barley were obtained from National Institute of Agricultural Research Tunisia (INRAT), National Institute of Agricultural Research Algeria (INRAA), National Research Centre, Egypt (NRC), and Agricultural Genetic Engineering Research Institute, Egypt (AGERI). For resistance genes amplification, two Egyptian barley genotypes El Awamah \& Awlad Ali were selected. The barley cultivar names, places and country of origin are listed in Table 1.

\subsection{Isozyme analysis}

To electrophoretically examine peroxidase (PER, E.C.1.11.1.7) isozymes, crude extraction of the twenty- nine genotypes from Algeria, Tunisia \& Egypt was done using $0.1 \mathrm{M}$ Tris- $\mathrm{HCl}$ buffer in $4^{\circ} \mathrm{C}$ for two hours (Gottlieb, 1981). Then, the homogenates were centrifuged at $14.000 \mathrm{rpm}$ for 20 minutes at $4{ }^{\circ} \mathrm{C}$ using Centrion K3 centrifuge (Centrion, UK). Electrophoretic separation of the extracts was carried out in $10 \%$ native PAGE (Laemmli, 1970). The peroxidase enzyme was stained as described by Soltis et al. (1983) as follows: gels were incubated in $100 \mathrm{ml}$ staining solution containing $0.05 \mathrm{M}$ acetate buffer $(\mathrm{pH}=5.0)$ and $65 \mathrm{mg}$ benzidine. Two $\mathrm{ml}$ of $0.1 \mathrm{M} \mathrm{CaCl}_{2}$ were added as a catalyst. Finally, two ml of $\mathrm{H}_{2} \mathrm{O}_{2}$ were added as the substrate and the gels were kept in refrigerator until dark brown bands appeared. All isozyme bands were assessed according to their relative distances. 
Table 1. Places, names and country of origin of the barley cultivars and landraces

\begin{tabular}{|c|c|c|}
\hline Serial & $\begin{array}{c}\text { Place of origin or } \\
\text { cultivar name }\end{array}$ & Country of origin \\
\hline 1 & Sidimehdi & Algeria \\
\hline 2 & Temasine & Algeria \\
\hline 3 & Kasrmegarine & Algeria \\
\hline 4 & RasEllouche & Algeria \\
\hline 5 & Saida & Algeria \\
\hline 6 & Tichedielt & Algeria \\
\hline 7 & Nailia & Algeria \\
\hline 8 & Rihone-03 & Algeria \\
\hline 9 & Azrir & Algeria \\
\hline 10 & Tozeurt & Tunisia \\
\hline 11 & Tozeur2 & Tunisia \\
\hline 12 & Manel & Tunisia \\
\hline 13 & SidiBeozid & Tunisia \\
\hline 14 & Kibilliz & Tunisia \\
\hline 15 & Tomban & Tunisia \\
\hline 16 & Gabes & Tunisia \\
\hline 17 & KairooaA & Tunisia \\
\hline 18 & Rihan & Tunisia \\
\hline 19 & Jerba & Tunisia \\
\hline 20 & Arish (Sinai) & Egypt \\
\hline 21 & Giza123 & Egypt \\
\hline 22 & Giza 126 & Egypt \\
\hline 23 & Giza 129 & Egypt \\
\hline 24 & Giza 125 & Egypt \\
\hline 25 & Giza 2000 & Egypt \\
\hline 26 & Giza 127 & Egypt \\
\hline 27 & Matrooh (Awama) & Egypt \\
\hline 28 & Giza 131 & Egypt \\
\hline 29 & Giza 130 & Egypt \\
\hline
\end{tabular}

\subsection{DNA extraction and RAPD analysis}

DNA isolation of the different barley cultivars, genotypes and landraces was performed using the CTAB method of Doyle and Doyle (1990). For RAPDPCR analysis, 2 random 10-mer primers OPA3 and OPG3 were used. The random primers used in our study were ordered from SNEF medical, Germany. PCR reactions were conducted in a total volume of $20 \mu \mathrm{l}$ reaction mix containing $2 \mu \mathrm{l}$ of $10 \times$ reaction buffer, containing $2 \mathrm{mM} \mathrm{MgCl} 2,2 \mu \mathrm{l}$ of $0.2 \mathrm{mM} \mathrm{dNTP}, 0.1 \mu \mathrm{l}$
$(0.5 \mathrm{U})$ of Taq DNA polymerase (Sigma, USA), $40 \mathrm{ng}$ of genomic template DNA, and 10 pmol primer in a preheated thermocycler (Biometra, Germany) under the following conditions: $3 \mathrm{~min}$ at $95^{\circ} \mathrm{C}$, followed by 44 cycles of $2 \mathrm{~min}$ at $92^{\circ} \mathrm{C}, 1 \mathrm{~min}$ at $37^{\circ} \mathrm{C}$, and $2 \mathrm{~min}$ at $72^{\circ} \mathrm{C}$. The reaction was finally incubated at $72^{\circ} \mathrm{C}$ for 10 min. For selecting the optimal conditions of the RAPD $\mathrm{PCR}$, different optimization experiments were performed. 
The PCR products were separated by electrophoresis on a $1 \%$ agarose gels using $1 \times$ TAE buffer. Then, gels were stained with ethidium bromide $(10 \mathrm{mg} / \mathrm{ml})$ and visualized under UV light. A 100 bp DNA ladder (Axygen, USA ) was used as a molecular DNA standard.

\subsection{Resistance sequences and primers selection}

Forty-six sequences showed resistance to different pathogens were retrieved from NCBI gene bank. These sequences were coded for different proteins included definsin (maize and wheat), superoxide dismutase (maize and wheat), catalase (barley and Cynodon). Six primer pairs were designed using Primer3 software. After primer selection with the Primer3 program, the complementarity of the primer pairs (primer dimmer and internal complementarity) was checked and the expected annealing temperatures were manually calculated. Table 2 contains the primer sequences, primers length and the expected PCR products in bp for the six primer pairs that were selected from resistance sequences, which were obtained from the NCBI gene bank.

Table 2: Oligonucleotide primers used for RT-PCR amplification

\begin{tabular}{|c|c|c|c|c|}
\hline Primer name & Sequence & $\begin{array}{l}\text { Primer } \\
\text { length }\end{array}$ & Sequence/plant & $\begin{array}{l}\text { Expected } \\
\text { PCR } \\
\text { fragments }\end{array}$ \\
\hline $\begin{array}{l}\text { AB089942P1 } \\
\text { AB089942P2 }\end{array}$ & $\begin{array}{l}\text { GGTGTGAAGCGAGCAAGC } \\
\text { CAGTGGCATCGTTATTACATCA }\end{array}$ & $\begin{array}{l}18 \mathrm{bp} \\
22 \mathrm{bp}\end{array}$ & Definsin/wheat & $522 \mathrm{bp}$ \\
\hline $\begin{array}{l}\text { AF092524P1 } \\
\text { AF092524P2 }\end{array}$ & $\begin{array}{l}\text { CTACGTCGCCCACTACAACAAG } \\
\text { CCAACAGCGGGAAACTCAAG }\end{array}$ & $\begin{array}{l}22 \mathrm{bp} \\
20 \mathrm{bp}\end{array}$ & SOD/wheat & 565 bp \\
\hline $\begin{array}{l}\text { AJ849917P1 } \\
\text { AJ849917P2 }\end{array}$ & $\begin{array}{l}\text { GGCCACAACGCTAGTACAATCTT } \\
\text { CATGCGTATCACTCAATCTGCC }\end{array}$ & $\begin{array}{l}23 \mathrm{bp} \\
22 \mathrm{bp}\end{array}$ & Definsin/Zea & 433 bp \\
\hline $\begin{array}{l}\text { CV064086P1 } \\
\text { CV064086P2 }\end{array}$ & $\begin{array}{l}\text { CGGCCATGGATCCCTACAAG } \\
\text { CTCCTGCATGTTGGTCTTCGG }\end{array}$ & $\begin{array}{l}20 \mathrm{bp} \\
21 \mathrm{bp}\end{array}$ & CatIso1/barley cDNA & $509 \mathrm{bp}$ \\
\hline $\begin{array}{l}\text { DN988165P1 } \\
\text { DN988165P2 }\end{array}$ & $\begin{array}{l}\text { GTATCTTCATGTCATTGCTCGC } \\
\text { CTCCGGCTGGTTCCTTTC }\end{array}$ & $\begin{array}{l}22 \mathrm{bp} \\
18 \mathrm{bp}\end{array}$ & CatIso3/Cynodon & $153 \mathrm{bp}$ \\
\hline $\begin{array}{l}\mathrm{X} 17564 \mathrm{P} 1 \\
\mathrm{X} 17564 \mathrm{P} 2\end{array}$ & $\begin{array}{l}\text { AGGGCACCATCTTTTTCACC } \\
\text { GCGACGCTCTTATTTCACGA }\end{array}$ & $\begin{array}{l}20 \mathrm{bp} \\
20 \mathrm{bp}\end{array}$ & $\mathrm{SOD} / Z e a$ & 516 bp \\
\hline
\end{tabular}

The primers were ordered from Metabion International AG

\subsection{RNA isolation}

For RNA isolation from the two barley genotypes, leaves of the 7 day old seedlings of the barley genotypes were used. To avoid any contamination with RNase, all solutions were treated overnight with DEPC at a final concentration of $0.1 \%$. All non-disposable equipment, like glass and porcelain, was cleaned with $0.5 \%$ $\mathrm{SDS} / 0.5 \mathrm{M} \mathrm{NaOH}$ and rinsed with DEPC treated water and wiped with $70 \%$ ethanol.

Total RNA was isolated using TRIzol reagent of the TriFast (PeqGOLD) extraction kit. In this method, 0.2 $0.5 \mathrm{~g}$ of fresh leaves was ground to fine powder in liquid nitrogen. The powder was added directly to an Eppendorf tube containing $0.5 \mathrm{ml}$ TRIzol reagent. The homogenate was incubated at room temperature (RT) for $5 \mathrm{~min}$. After adding $0.2 \mathrm{ml}$ chloroform, the tube was repeatedly inverted by hand for $15 \mathrm{sec}$. The mixture was incubated for 15 - $20 \mathrm{~min}$ at RT. Then, the upper aqueous phase was separated by centrifugation at 12000 rpm for $15 \mathrm{~min}$ at $4^{\circ} \mathrm{C}$. The RNA was precipitated using 1 vol. isopropanol for $10 \mathrm{~min}$ at RT and afterwards by centrifugation at $12000 \mathrm{rpm}$ for $10 \mathrm{~min}$ at $4^{\circ} \mathrm{C}$. The pellet was washed with $70 \%$ ethanol and resuspended in DEPC treated water $(0.943 \mathrm{~g} / \mathrm{ml}$, BioBasic INC). To check the quality and quantity of the isolated RNA, RNA agarose gel electrophoresis was performed. Electrophoresis was carried out on $1.5 \%$ agarose gel for $1 \mathrm{~h}$ at $70 \mathrm{~V}$.

\subsection{RT-PCR analysis}

RT-PCR was carried out using Ready-To-Go RT-PCR Beads kit (Amersham Biosciences). Each bead is optimized to allow the first-strand cDNA synthesis and PCR reactions to proceed sequentially (One-step Protocol for RT-PCR). In the One-step protocol, 
primers for the first-strand cDNA synthesis and PCR were added along with the template to an RT-PCR Bead.

First, for each reaction tube, $39 \mu \mathrm{DEPC}$-treated water was added. The tube was taped to mix the water with the bead. To dissolve the bead, the tube was incubated on ice for $5 \mathrm{~min}$. and the tube contents were gently pipetted up and down. After that, to each bead (contains 2 units of Taq DNA polymerase, $10 \mathrm{mM}$ Tris- $\mathrm{HCl}, 60$ $\mathrm{mM} \mathrm{KCl}, 1.5 \mathrm{mM} \mathrm{MgCl} 2200 \mu \mathrm{M}$ dNTPs, MuLV reverse transcriptase, RNAguard ${ }^{\mathrm{TM}}$ Ribonuclease Inhibitor and stabilizer when brought to a final volume of $50 \mu \mathrm{l}) 1 \mu \mathrm{l}$ of the first-strand primer $(0.5 \mu \mathrm{g}), 5 \mu \mathrm{l}$ of 10 pmol PCR primer pairs (resistance sequences based primers) and $5 \mu \mathrm{l}$ of the template RNA were added.

For positive control reaction, $50 \mu \mathrm{l}$ of DEPC-treated water were added to control mix bead and then the entire contents of the control tube were transferred into a tube containing a RT-PCR Bead. The reaction tubes were incubated at $42^{\circ} \mathrm{C}$ for $15-30 \mathrm{~min}$ in heat block or thermal cycler. Then, the reaction tubes were incubated at $95^{\circ} \mathrm{C}$ for $5 \mathrm{~min}$ in order to inactivate the reverse transcriptase. The PCR analysis was carried out in MiniCycler $^{\mathrm{TM}}$ (MJ Research) thermocycler for 30 cycles with a 1 min denaturation step at $94^{\circ} \mathrm{C}, 1$ min annealing at $58^{\circ} \mathrm{C}$ and $1 \mathrm{~min}$ extension at $72^{\circ} \mathrm{C}$. After RT-PCR amplification, the PCR products were resolved on $2 \%$ agarose gel electrophoresis and the amplification profiles of the primer pairs were analyzed.

\subsection{Data analysis}

Peroxidase loci were labeled sequentially with those migrating closest to the anodal end designated as number 1 , while alleles at each locus were labeled alphabetically from the most anodal band. A tree illustrating the genetic diversity among barley landraces and varieties, using unweighted pair-group method with arithmetic average (UPGMA), was generated based on peroxidase isozymes data using NTSYS-pc version 2.1 (Rohlf, 2000). The RAPD amplicons (bands) were recorded as 0 (absence) or 1 (presence) and were also analyzed by cluster analysis using the UPGMA method using the NTSYS-pc version 2.1. The goodness of fit of the cluster analysis, for both of isozymes and RAPD data, was determined by calculating the cophenetic value matrix from the tree matrix in order to carry out the Mantel test (Mantel, 1967) to determine the agreement between the two matrices.

\section{RESULTS}

\subsection{PER isozyme analysis}

Only three loci (PER 1, PER 2 and PER 3) were obtained from peroxidase enzyme analysis in the 29 accessions and varieties of barley. Out of these three loci, two loci (PER 2 and PER 3) were polymorphic in all accessions obtained from Algeria and Tunisia. All the three loci (PER 1 "one band", PER 2 "2 bands" and PER 3 "one band") were monomorphic in Egyptian varieties and landraces, where three accessions (Giza 129, Matrouh-Awama and Giza 131) showed one band with slower electrophoretic mobility. PER 1 and PER 3 were monomorphic with only one band shown in the Egyptian accessions and varieties. PER 3 displayed three polymorphic isozymes (bands) in the Algerian and Tunisian landraces. However, in case of PER 1 and PER 2, two polymorphic bands were observed in Algerian accessions. Nevertheless, in the Tunisian accessions, PER 1 (one band) was monomorphic and PER 2 (one band) was also monomorphic. Three Tunisian accessions (Tomban, Gabes and KairooaA) showed one unique allele in locus PER 2.

Based on the profiles of peroxidase isozymes, cluster analysis grouped all Egyptian barley varieties into one main cluster group at a distance of 1.5 (Fig. 1). However, only one landrace (Matrouh) was contained into a separate subgroup with two accessions (Manel and Tozeurt) from Tunisia and one accession (Sidimehdi) from Algeria. Similarly, Algerian and Tunisia accessions were grouped into one main at the same distance (1.5). Two accessions (Azrir: Algeria and Gabes: Tunisia) were found in one of the subclusters with two Egyptian barley varieties. A unique main cluster contained only one Algerian accession (Temasine), see Fig. 1. Cophenetic correlation based Mantel t-test was $r=0.800$, which indicated a good fit to the dendrogram obtained with the cluster analysis. 


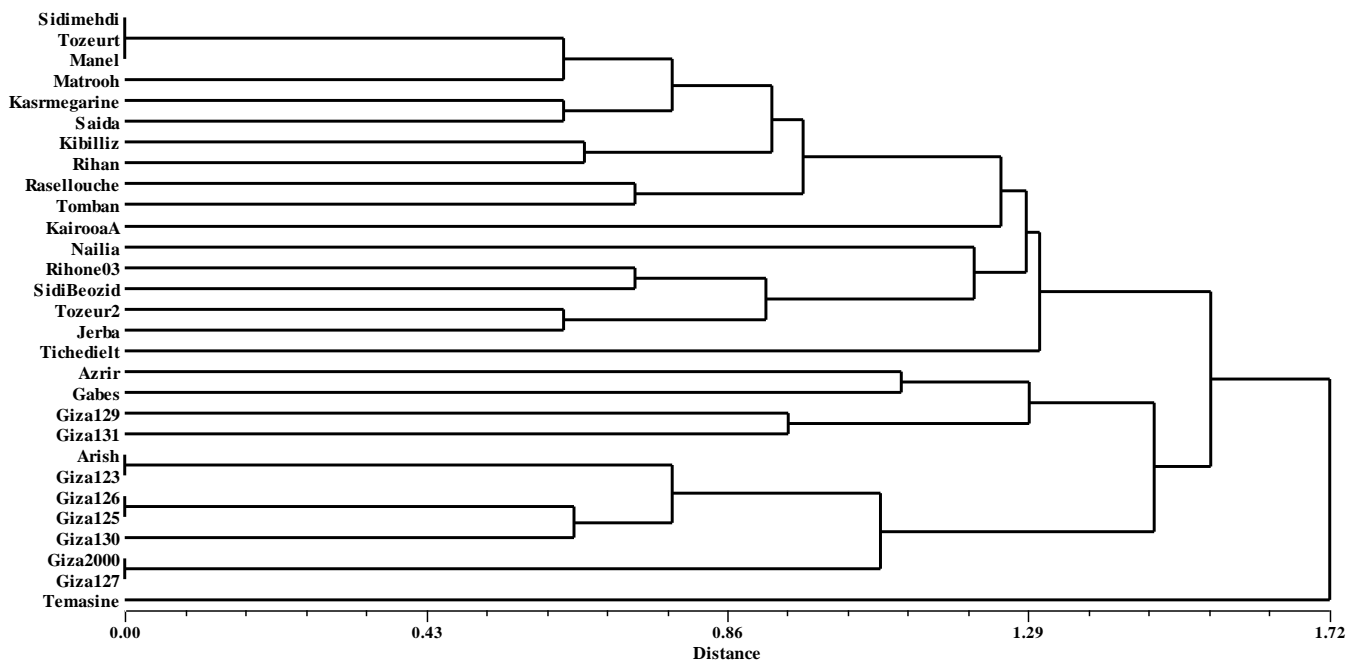

Figure 1: Cluster analysis of the isozymes-derived data of 29 barley accessions collected from three North African countries

\subsection{RAPD analysis}

RAPD analysis based on two random primers (OPA3 and OPG3) showed that about $60 \%$ of amplified bands were polymorphic. The number of bands (alleles) ranged from 3 to 12 per primer, with an average of 6 per primer. Cluster analysis based on RAPD data revealed that the two accessions (Sidimehdi and Temasine) from Algeria were clearly separated at a distance of 2.47 as two identical genomes from all other barley accessions. The Egyptian accessions were grouped into two obvious groups; one contained 4 accessions (Giza126, Giza2000,
Giza127 and Giza125) and the second contained two accessions (Giza123 and Giza129). However, only one accession (Giza130) was out of these two groups. Moreover, it was obvious that the accessions of each group were genetic invariable (showed high similarity). The Tunisian accessions showed no distinct clustering. The most high dissimilarities were revealed by the Algerian accessions (Fig. 2). Cophenetic correlation based on Mantel t-test, used to measure the goodness of fit of RAPD cluster analysis, was $\mathrm{r}=0.977$, which showed a very good fit to the generated dendrogram.

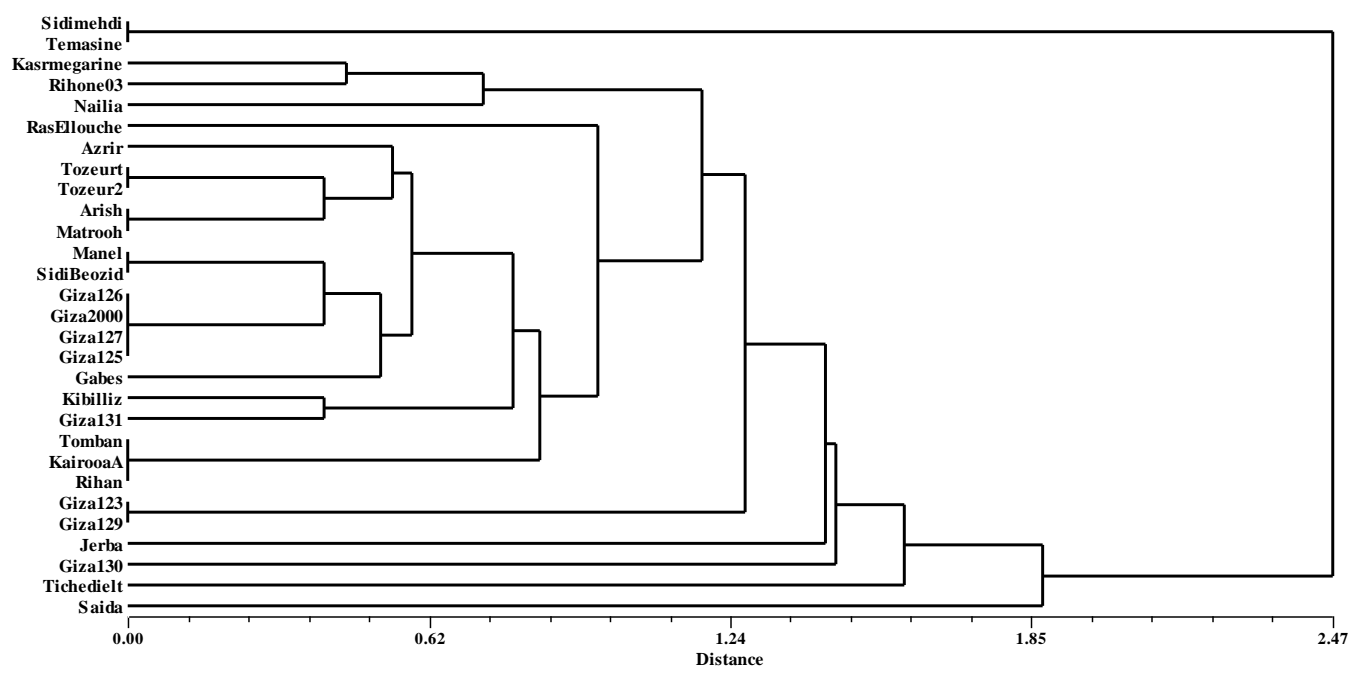

Figure 2: Cluster analysis of the RAPD-derived data of 29 barley accessions collected from three North African countries

\subsection{RT-PCR and cDNA analysis}

The total RNA was isolated with TriFast method, which ensured high quality total RNA in sufficient amount.
RNA was checked for quality and quantity using agarose gel electrophoresis. To amplify the selected resistance gene-sequences from the Egyptian barley genotypes, which may represent candidate sequences 
for the resistance gene analogs of barley; comparative RT-PCR amplifications with each primer pair (Table 2) were performed. The total RNA isolated from two Egyptian barley genotypes (El-Awamah and Awlad-Ali) was used as template for RT-PCR analysis. The genomic DNA of the barley genotypes was also used to check and compare the amplification profiles when using RNA and DNA as templates. In case of DNA template, ordinary PCR analysis was performed.

Figure 3 showed that the primer combinations AB089942P1P2 and CV064086P1P2 amplified 3 weak amplicons in both barley genotypes (El-Awamah and Awlad-Ali). The primer pair AF092524P1P2 successfully amplified two PCR amplicons of approximately (340 \& 220 bp) and (360 \& 270 bp), respectively in both barley genotypes (Fig. 3). However, primer pair DN988165P1P2 gave only one amplicon in both barley genotypes (El-Awamah and Awlad-Ali) of 250 and $270 \mathrm{bp}$, respectively. The primer pairs AJ849917P1P2 and X17564P1P2 failed to amplify any fragments from both barley genotypes.

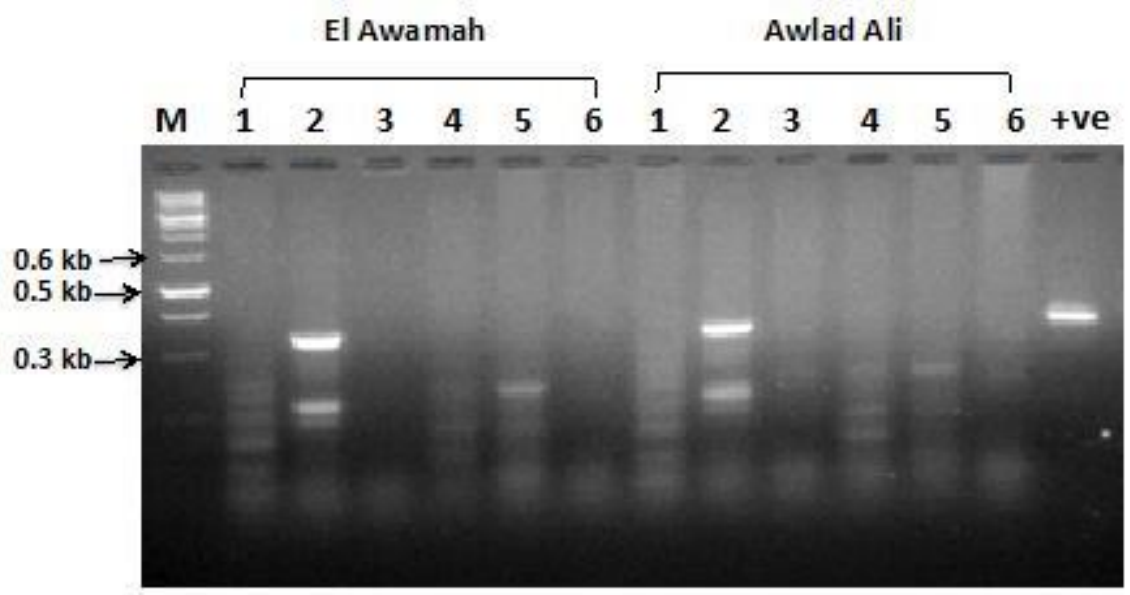

Figure 3: PCR amplification of specific DNA markers based on primers derived from resistance gene ortholog sequences, cDNA was used as template. +ve: positive control

Although, the primer combinations AB089942P1P2 and CV064086P1P2 have amplified three faint bands in the One-Step RT-PCR, they were successful to amplify only one specific PCR fragments when genomic barley DNA (El-Awamah) was used as template. The two PCR fragments were of approximately $230 \mathrm{bp}$ and $200 \mathrm{bp}$, respectively (Fig. 4). Similarly, primer pair DN988165P1P2 amplified only one specific fragment of $700 \mathrm{bp}$. The X17564P1P2 primer pair failed to amplify any PCR product, while primer pairs AF092524P1P2 and AJ849917P1P2 amplified very faint fragment of $450 \mathrm{bp}$.

\section{El Awamah}

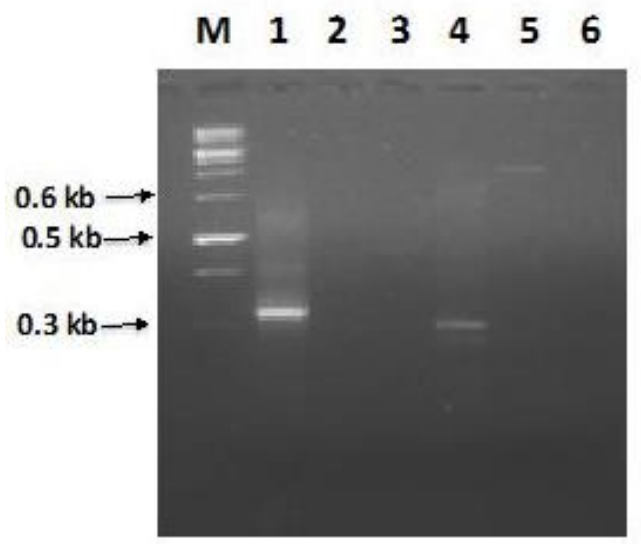

Figure 4: PCR amplification of specific DNA markers based on primers derived from resistance gene ortholog sequences, genomic DNA extracted from El-Awamah landrace was used as template 


\section{DISCUSSION}

In this study, high genetic variability was observed among the barley landrace accessions and varieties collected from the three North African countries (Algeria, Egypt and Tunisia). However, relatively low genetic diversity was shown among the landrace accessions and varieties from the same region. In addition, development of molecular markers based on pathogen-resistance gene sequences was successful and two gene-based primer pairs amplified specific DNA fragments, which could be used in barley crop improvement.

The possible explanation of the low genetic diversity among varieties (collected from one country) is that they have a relatively narrow gene pool. Similar finding has been observed in the polish old oat cultivars, where low genetic variation of the old cultivars collection was noticed, which has been related to the entirely limited gene pool of such cultivars (Boczkowska et al., 2014).

Evaluation of the degree of genetic diversity within cultivated barley and its related wild germplasm is necessary for barley crop improvement and for the conservation of barley genetic resources (Boczkowska et al., 2014; Gepts, 2006). Therefore, estimation of genetic diversity of the North African barley landrace accessions and varieties were examined using isozymes and RAPD molecular markers.

RAPD markers provide a powerful tool for studying all aspects of genetic variability and genetic structure of the populations. Genetic data derived from isozymes are more robust this due to isozymes are codominant markers. However, isozyme analysis is restrained because fewer number of loci are generated. RAPDs are dominant markers. Therefore, there is less information per band. However, RAPD analysis has several advantages over other marker types: it has more loci that can be tested with RAPD, it is simple, has low cost, and it needs little amount of plant DNA (Garcia Mas et al., 2000).

It is well known that genetic variability of the wild populations is essential for plants to be adapted to environment (Nevo et al., 1997). Canadian durum wheat cultivars, which were analyzed by AFLP markers, showed that the cultivars that had been bred from landraces were characterized by higher genetic heterogeneity compared to those that were derived from commercial cultivars (Soleimani et al., 2002).

The current results indicated that it is possible to use specific primers based on the resistance gene sequences to amplify PCR products using cDNA or DNA as templates. Also, the amplified PCR products would help in identification of RGAs from barley. Wild barley and Middle Eastern landraces have already proven to be a very beneficial source of genes for modern crop improvement (Ellis et al., 2000). The most obvious example is the development of barley varieties that have mlo allele, which showed resistant to powdery mildew (Thomas et al., 1998).

Similar approach was used to develop gene-based markers, which were used to construct a dense linkage map in yellow fever mosquito Aedes aegypti (Linnaeus in Hasselquist, 1762). In this approach, cDNA sequences were downloaded from GenBank and primers were set to amplify PCR fragments of about $500 \mathrm{bp}$ (Fulton et al., 2001). The identification of QTL and in special cases, gene cloning, are steps in the process of building a program for the genetic manipulation of abiotic stress tolerance (Ellis et al., 2000) without using transformation.

Fourmann et al. (2001) reported the development and mapping in Brassica napus $\mathrm{L}$. of a series of resistancegene analogs based on existing sequences of nucleotidebinding resistance genes. Some of the sequences could be amplified in B. oleracea $\mathrm{L}$. and B. rapa $\mathrm{L}$. and were employed as helpful markers, which were linked to disease resistance in the three major cultivated Brassica species.

Recently, barley genetic resources were mined for genes and alleles relevant for non-specific resistance (NR) to powdery mildew, which is caused by Blumeria graminis (DC.) Speer.f. hordei (Bgh). In that study, eleven candidate genes were identified, where they showed significant SNP or haplotype associations with the $B g h$ phenotypes in a worldwide collection of spring barley (Spies et al., 2012).

Marker assisted selection (MAS) signifies that DNA markers, which are tightly-linked to target loci are exploited as a substitute for assist population phenotyping (Collard et al., 2005). In our study, some of the sequences amplified specific DNA fragments (Fig. 4), which could also be used for marker assisted selection in the breeding program of barley crop improvement.

Similarly, Giovanelli et al. (2002) developed gene-based markers, which were associated with cotyledon-stage downy mildew (Hyaloperonospora parasitica (Pers.) Constant.) resistance in broccoli. They proposed that such markers could be used for marker-assisted selection to generate downy mildew resistant varieties. 
In conclusion, genetic diversity analysis revealed that relatively low genetic variability was found among the landraces and varieties from the same region. Using RT-
PCR-based approach, it was successful to amplify genebased DNA marker bands, which could be employed in the breeding of disease-resistant barley genotypes.

\section{REFERENCES}

Barua U.M., Chalmers, K.J., Hackett, C.A., Thomas, W.T.B., Powell, W., Waugh, R. (1993). Identification of RAPD markers linked to a Phynchosporium secalis resistance locus in barley using near isogenic lines and bulked segregant analysis. Heredity, 71, 177-184. doi:10.1038/hdy.1993.122

Bhattacharyya, U., Pandey, S.K., Dasgupta, T. (2014). Identification of EST-SSRs and FDM in sesame (Sesamum indicum L) through data mining. Scholarly Journal of Agricultural Science, 4(2), 6069.

Boczkowska, M., Harasimiuk, M., Onyśk, A. (2014). Studies on genetic variation within old polish cultivars of common oat. Cereal Research Communications. doi:10.1556/CRC.2014.0025.

Brown, A.D.H., Burdon, J.J., Grace, J.P. (1990). Genetic structure of Glycine canescens. A perennial relative of soybean. Theoretical and Applied Genetics, 79, 729-736. doi:10.1007/BF00224237

Ceccarelli, S., Grando S., van Leur, J.A.G. (1995). Barley landraces of the Fertile Crescent offer new breeding options for stress environments. Diversity, 112-113.

Chalmers, K.J., Barua, U.M., Hackett, C.A., Thomas, W.T.B., Waugh, R., Powell, W. (1993). Identification of RAPD markers linked to genetic factors controlling the milling energy requirement of barley. Theoretical and Applied Genetics, 87, 314-320. doi:10.1007/BF01184917

Collard, B.C.Y., Jahufer, M.Z.Z., Brouwer, J.B., Pang, E.C.K. (2005). An introduction to markers, quantitative trait loci (QTL) mapping and markerassisted selection for crop improvement: The basic concepts. Euphytica, 142, 169-196. doi:10.1007/s10681-005-1681-5

Dangl, J.L. \& Jones, J.D. (2001). Plant pathogens and integrated defence responses to infection. Nature, 411, 826-833. doi:10.1038/35081161

Devos, K.M. \& Gale M.D. (1992). The use of random amplified polymorphic DNA markers in wheat. Theoretical and Applied Genetics, 84, 567-572. doi:10.1007/bf00224153

Doyle, J.J. \& Doyle, J.L. (1990). Isolation of plant DNA from fresh tissue. Focus, 12, 13-15.
Ellis, R.P., Forster, B.P., Robinson, D., Handley, L.L., Gordon, D.C., Russell, J.R. et al. (2000). Wild barley: a source of genes for crop improvement in the 21st century?. Journal of Experimental Botany, 51, 9-17. doi:10.1093/jxb/51.342.9

Fernández, M.E., Figueiras, A.M., Benito, C. (2002). The use of ISSR and RAPD markers for detecting DNA polymorphism, genotype identification and genetic diversity among barley cultivars with known origin. Theoretical and Applied Genetics, 104, 845-851. doi:10.1007/s00122-001-0848-2

Fetch, T.G., Steffenson B., Nevo, E. (2003). Diversity and sources of multiple disease resistance in Hordeum spontaneum Plant Disease Journal, 87, 1439-1448.

Fourmann, M., Chariot, F., Froger, N., Delourme, R., Brunel, D. (2001). Expression, mapping, and genetic variability of Brassica napus disease resistance gene analogues. Genome, 44, 1083-1099. doi:10.1139/g01-098

Fulton, R.E., Salasek, M.L., DuTeau, N.M., Black, W.C. (2001). SSCP analysis of cDNA markers provides a dense linkage map of the Aedes aegypti genome. Genetics, 158, 715-726.

Garcia Mas, J., Oliver, M., Gomez Paniagua, H., de Vicente, M.C. (2000). Comparing AFLP, RAPD and RFLP markers for measuring genetic diversity in melon. Theoretical and Applied Genetics, 101, 860-864. doi:10.1007/s001220051553

Gepts, P. (2006). Plant genetic resources conservation and utilization: The accomplishments and future of a societal insurance policy. Crop Science, 46, 22782292. doi:10.2135/cropsci2006.03.0169gas

Giovanelli, J.I., Farnham, M.W., Wang, M., Strand, A.E. (2002). Development of sequence characterized amplified region markers linked to downy mildew resistance in broccoli. American Society for Horticultural Science, 127, 597-602.

Gottlieb, LD. (1981). Electrophoretic evidence and plant populations. Progress Photochemistry, 7, 146.

Joshi, C.P. \& Nguyen, H.T. (1993). RAPD (Random amplified polymorphic DNA) analysis based on intervarietal genetic relationships among hexaploid 
wheats. Plant Science, 93, 95-103. doi:10.1016/0168-9452(93)90038-2

Laemmli, U.K. (1970). Cleavage of structural proteins during the assembly of the head of bacteriophage T4. Nature, 227, 680-685. doi:10.1038/227680a0

Mantel, N.A. (1967). The detection of disease clustering and a generalized regression approach. Cancer Research, 27, 209-220.

Matus, I.A. \& Hayes, P.M. (2002). Genetic diversity in three groups of barley germplasm assessed by simple sequence repeats. Genome, 45, 1095-1106. doi:10.1139/g02-071

Mayer, K.F.X., Waugh, R., Brown, J.W.S., Schulman, A., Langridge, P., Platzer, M., et al. (2012). A physical, genetic and functional sequence assembly of the barley genome. Nature, 491, 711-716. doi:10.1038/nature11543

Nevo, E. 1992. Origin, evolution, population genetic and resources for breeding of wild barley. Hordeum spontaneum in the fertile Crescent. In: Shewry PR (ed) Barley: Genetics, Biochemistry, Molecular Biology and Biotechnology (pp.19-143). CAB international: Wallingford.

Nevo, E., Kirzhner V.M., Beiles, A., Korol, A.B. (1997). Selection versus random drift: long-term polymorphism persistence in small populations (evidence and modeling). Philosophical Transactions of the Royal Society : Biological Sciences, 352, 381-389. doi:10.1098/rstb.1997.0028

Parchman, T.L., Geist, K.S., Grahnen, J.A., Benkman, C.W., Buerkle, C.A. (2010). Transcriptome sequencing in an ecologically important tree species: Assembly, annotation, and marker discovery. BMC Genomics, 11, 180. doi:10.1186/1471-2164-11-180

Rohlf, F.J. (2000). NTSYS-pc: Numerical Taxonomy and Multivariate Analysis System. Version 2.1. Exeter Software, Setauket, NY.

Sánchez de la Hoz, M.P., Dávila, J.A., Loarce, Y., Ferrer, E. (1996). Simple sequence repeat primers used in polymerase chain reaction amplifications to study genetic diversity in barley. Genome, 39, 112117. doi:10.1139/g96-015

Shen, Y., Lebold, K., Lansky, E.P., Traber, M.G., Nevo, E. (2011). "Tocol-omic" diversity in wild barley. Chemistry \& Biodiversity, 8, 2322-2330. doi:10.1002/cbdv.201000363

Soleimani, V.D., Braum, B.R., Johnson, D.A. (2002). AFLP and pedigree-based genetic diversity estimates in modern cultivars of durum wheat [Triticum turgidum L. subsp. durum (Desf.) Husn.]. Theoretical and Applied Genetics, 104, 350-357. doi:10.1007/s001220100714

Soltis, D.E., Haufler, C.H., Darrow, D.C., Gastony G. J. (1983). Starch gel electrophoresis of ferns: a compilation of grinding buffers, gel and electrode buffers, and staining schedules. American Fern Journal, 73, 9-27. doi:10.2307/1546611

Spies, A., Korzun, V., Bayles, R., Rajaraman, J., Himmelbach, A., Hedley, P.E. et al. (2012). Allele mining in barley genetic resources reveals genes of race-non-specific powdery mildew resistance. Frontiers in Plant Science, 2, 113-135. doi:10.3389/fpls.2011.00113

Tanyolac, B. (2003). Inter-simple sequence repeats (ISSR) and RAPD variation among wild barley (Hordeum vulgare subsp. spontaneum) populations from west Turkey. Genetic Resources and Crop Evolution, 50, 611-614. doi:10.1023/A:1024412814757

Thomas, W.T.B., Baird, E., Fuller, J.D., Lawrence, P., Young, G.R., Russell J. et al. (1998). Identification of a QTL decreasing yield in barley linked to Mlo powdery mildew resistance. Molecular Breeding, 4, 381-393. doi:10.1023/A:1009646115967

Vanhala, T.K. \& Stam, P. (2006). Quantitative trait loci for seed dormancy in wild barley (Hordeum spontaneum C. Koch). Genetic Resources and Crop Evolution, 53,1013-1019. doi:10.1007/s10722-0047368-2 